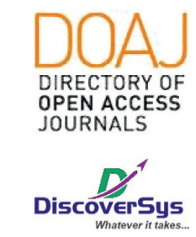

Published by DiscoverSys

\title{
Hubungan antara TIL (Tumor Infiltrating Lymphocyte) dan MAI (Mitotic Activity Index) dengan kejadian metastase kelenjar getah bening (KGB) aksila pada operable breast cancer di RSUP Sanglah, Denpasar
}

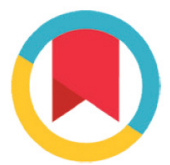

CrossMark

I Gede Aditya Krishna Santhi ${ }^{1 *}$, I Nengah Wiadnyana Steven Christian², I Gede Raka Widiana

\section{ABSTRACT}

Background: Evaluation of the degree of cell proliferation in tumor tissue is used to assess tumor progression. Assessment of the mitotic index has been used as a "gold standard" in assessing tumor aggressiveness. Therefore, this study aims to determine the relationship between Tumor Infiltrating Lymphocyte (TIL) and Mitotic Activity Index (MAI) with the incidence of axillary lymph node metastasis (KGB) among operable breast cancer at Sanglah Hospital Denpasar.

Methods: A cross-sectional analytic studies among 53 samples of post-MRM (Modified Radical Mastectomy) breast cancer patients who were treated at Sanglah General Hospital and had medical records (clinical, histopathological data) were enrolled in this study. The eligible sampling technique was carried out on the patient's medical record in the Department of Surgical Oncology, Faculty of
Medicine, Udayana University, Sanglah General Hospital throughout 2016-2018. Data analysis of TIL and MAI with the incidence of axillary GB metastases in operable breast cancer patients was performed using SPSS version 20 software for Windows.

Results: The average age of patients was $51.8 \pm 10.3$ years where mostly worked as housewife (50.9\%) and tumor size T2 (66.0). The Chi-square test showed that patients with low TIL $(P=0.627)$, intermediates TIL ( $P=0.339)$ and $\mathrm{MAI} \geq 25 / 10 \mathrm{lp}(\mathrm{P}=0.531)$, MAI 13-24 / $10 \mathrm{lp}(P=0.531)$ were not found a statistically significant association with axillary lymph node metastases.

Conclusion: There was no significant association between TIL and MAI with the incidence of axillary GB metastasis in the Operable Breast Cancer at Sanglah Hospital Denpasar
'Program Pendidikan Dokter Spesialis Bedah Umum, Fakultas Kedokteran Universitas Udayana, Bali, Indonesia

${ }^{2}$ Departemen Bedah, Divisi Bedah Onkologi, Fakultas Kedokteran Universitas Udayana, RSUP Sanglah, Bali, Indonesia ${ }^{3}$ Departemen IImu Penyakit Dalam, Fakultas Kedokteran Universitas Udayana, RSUP Sanglah, Bali, Indonesia

\section{*Korespondensi:}

I Gede Aditya Krishna Santhi;

Program Pendidikan Dokter

Spesialis Bedah Umum, Fakultas Kedokteran Universitas Udayana, Bali, Indonesia; igedeadityakrishnasanthi@gmail. com

Diterima : 05-03-2019

Disetujui : 28-07-2019

Diterbitkan : 01-08-2019
Keywords: TIL, MAl, metastases, axillary lymph nodes

Cite This Article: Santhi, I.G.A.K., Christian, I.N.W.S.., Widiana, I.G.R. 2019. Hubungan antara TIL (Tumor Infiltrating Lymphocyte) dan MAI (Mitotic Activity Index) dengan kejadian metastase kelenjar getah bening (KGB) aksila pada operable breast cancer di RSUP Sanglah, Denpasar. Intisari Sains Medis 10 (2): 465-470. D01: 10.1556/ism.v10i2.427

\section{ABSTRAK}

Latar belakang: Evaluasi dari derajat proliferasi sel dalam jaringan tumor digunakan untuk menilai progresifitas tumor. Penilaian indeks mitosis telah digunakan sebagai "gold standard" bertujuan untuk mengetahui hubungan antara Tumor Infiltrating Lymphocyte (TIL) dan Mitotic Activity Index (MAI) dengan kejadian metastasis kelenjar getah bening (KGB) aksila pada operable breast cancer di RSUP Sanglah Denpasar.

Metode: Penelitian potong-lintang analitik terhadap 53 sampel pasien kanker payudara post MRM (Modified Radical Mastectomy) yang berobat di RSUP Sanglah dan mempunyai catatan medis (data klinis, histopatologis) dilibatkan dalam studi ini. Teknik eligible sampling dilakukan pada rekam medis pasien di Bagian/ SMF Bedah Onkologi Fakultas Kedokteran Universitas Udayana RSUP dalam menilai agresivitas tumor. Oleh karena itu penelitian ini
Sanglah sepanjang 2016-2018. Analisis data TIL dan MAI dengan kejadian metastase KGB aksila pada pasien operable breast cancer dilakukan menggunakan perangkat lunak SPSS versi 20 untuk Windows.

Hasil: Rata-rata usia pasien adalah $51,8 \pm 10,3$ tahun dimana sebagian besar bekerja sebagai IRT (50,9\%) dan ukuran tumor T2 $(66,0)$. Uji Chi-square menunjukkan bahwa pasien dengan low TIL $(P=0,627)$, intermediate TIL $(P=0,339)$ dan MAI $\geq 25 / 10 \mathrm{Ip}$ $(P=0,531)$, MAl 13-24 /10 lp $(P=0,531)$ tidak dijumpai adanya hubungan bermakna secara statistik dengan kejadian metastase KGB aksila.

Simpulan: Tidak terdapat hubungan bermakna antara TIL maupun MAI dengan kejadian metastasis KGB aksila pada Operable Breast Cancer di RSUP Sanglah Denpasar
Kata kunci: TIL, MAl, metastase, KGB aksila

Site Pasal ini: Santhi, I.G.A.K., Christian, I.N.W.S.., Widiana, I.G.R. 2019. Hubungan antara TIL (Tumor Infiltrating Lymphocyte) dan MAI (Mitotic Activity Index) dengan kejadian metastase kelenjar getah bening (KGB) aksila pada operable breast cancer di RSUP Sanglah, Denpasar. Intisari Sains Medis 10 (2): 465-470. D01: 10.1556/ism.v10i2.427 


\section{PENDAHULUAN}

Kanker payudara merupakan penyakit yang menduduki urutan ketiga di Eropa dan United State sebagai jenis kanker yang menyebabkan kematian. ${ }^{1}$ Studi dua dekade terakhir mengungkapkan bahwa Tumor microenvironment (TME) juga merupakan penentu penting perilaku tumor. ${ }^{1}$ Tumor padat umumnya terdiri dari berbagai sel kekebalan tubuh, termasuk limfosit T dan B, sel NK (Natural Killer), makrofag, dan neutrofil. Imunitas adaptif dan imunosupresi selalu menunjukkan tingkat ekspresi yang berbeda pada tumor, dan banyak gen kekebalan terkait dengan inflamasi. Interaksi antara sel imunitas menentukan induksi atau penghambatan perkembangan tumor, angiogenesis, dan metastasis. ${ }^{2}$ Sistem imunitas mempengaruhi surveillance pada pasien kanker. ${ }^{3}$

Penelitian yang dilakukan oleh Aaltomaa menunjukan bahwa dari 489 pasien kanker payudara, terdapat 104 pasien dengan low TIL, 145 pasien dengan intermediate TIL, 240 pasien dengan high TIL. Pasien dengan klinis KGB aksila positive sebanyak 224 pasien, klinis KGB aksila negative 265 pasien. $^{4}$

Selain itu, studi lain yang dilakukan oleh Jan J. Jobsen melaporkan bahwa dari 2.048 breastconserving specimens, $66,1 \%$ menunjukkan MAI rendah $(\leq 12), 12.3 \%$ MAI tinggi $(>12)$, dan dalam $21.6 \%$ kasus, MAI tidak diketahui. Untuk wanita $>$ 55 tahun, didapatkan $63.3 \%$ rendah, tinggi $7,3 \%$, dan $29.4 \%$ tidak diketahui ${ }^{5}$

Proliferasi maupun penanda hematologi telah dikenali sebagai "hallmark" dari kanker dan merupakan salah satu faktor prognostik kanker. ${ }^{6}$ Evaluasi dari derajat proliferasi sel dalam jaringan tumor digunakan untuk menilai progresifitas tumor. ${ }^{7}$ Penilaian indeks mitosis telah digunakan sebagai "gold standard" dalam menilai agresivitas tumor. ${ }^{8}$ Berpijak pada permasalahan di atas maka tujuan penelitian ini adalah untuk mengetahui hubungan respon imun pada tumor dalam hal ini sel Lymphocyte dan aktifitas pembelahan sel tumor dengan kejadian penyebaran kanker ke KGB aksila pada pasien operable breast cancer.

\section{METODE PENELITIAN}

Penelitian ini merupakan suatu penelitian rancangan potong lintang analitik, menggunakan pola tersaran (nested design) terhadap 53 pasien untuk mengetahui hubungan antara TIL dan MAI dengan kejadian metastase KGB aksila pada pasien operable breast cancer di RSUO Sanglah tahun 2016-2018. Adapun kriteria inklusi dalam studi ini adalah penderita kanker payudara yang berobat ke RSUP Sanglah dan empunyai catatan medis (data klinis, histopatologi) yang lengkap. Apabila jumlah kelenjar aksila pada "mapping" kurang dari 6 KGB dan kejadian kanker terjadi pada laki-laki maka sampel di eksklusi.

Tumor Infiltrating Lymphocyte (TIL) merupakan persentase jumlah infiltrasi sel limfosit pada tumor dimana terbagi atas 3 kelompok yakni: 1) Rendah, apabila didapatkan infiltrasi limfosit pada tumor sebanyak $0-10 \%$; 2) Sedang atau intermediate, jika didapatkan infiltrasi limfosit pada tumor sebanyak 20-40\%; dan 3) Tinggi, jika didapatkan infiltrasi limfosit pada tumor sebanyak 50-90\%.. Sedangkan Mitotic Activity Index (MAI) merupakan jumlah mitosis sel pada gambaran histopatologi dalam 10 lapangan pandang besar (High Power Field), diukur dengan mikroskop berdiameter 0,65 mm, yang terbagi atas 3 kelompok besar: 1) Skor 1, jika didapatkan jumlah mitosis $\leq 12$ per 10 lapangan pandang; 2) Skor 2, jika didapatkan jumlah mitosis 13-24 per 10 lapangan pandang; dan 3) jika didapatkan jumlah mitosis $\geq 25$ per 10 lapangan pandang.

Analisis data dilakukan menggunakan piranti lunak SPSS versi 20 untuk windows dimana meliputi analisis univariat untuk mengetahui sebaran data numerik dalam bentuk rata-rata dan simpangan baku, sedangkan data kategorikal ditampilkan dalam bentuk frekuensi relative. Analisis regresi logistik dilakukan untuk mengetahui hubungan antara satu variabel bebas dengan satu variabel tergantung. Hasil penelitian dikatakan bermakna secara statistik apabila nilai $\mathrm{P}<0.05$ pada interval kepercayaan 95\%. Data di analisis menggunakan piranti lunak SPSS versi 20 untuk Windows.

\section{HASIL}

Penelitian ini dilakukan dari tahun 2016 hingga 2018 dengan jumlah sampel 53 pasien. Subyek penelitian adalah pasien operable breast cancer dan menjalani tindakan "Modified Radical Mastectomy" dan mempunyai catatan medis (data klinis, histopatologis) yang berobat di RSUP Sanglah. Adapun karakteristik subyek penelitian ditunjukkan pada Tabel 1.

Pada Tabel 1 diatas didapatkan data karakteristik subyek penelitian berdasarkan umur pasien dengan rerata usia 51,8 $\pm 10,3$ tahun. Sebagian besar pasien bekerja sebagai IRT yakni sebanyak 27 pasien (50,9\%). Berdasarkan suku, sebagian besar pasien berasal dari Bali yakni 45 pasien $(84,9 \%)$ dan luar Bali 8 pasien $(15,1 \%)$. Latar belakang pendidikan pasien paling banyak adalah perguruan tinggi (PT) yakni sebesar 21 pasien $(39,6 \%)$. Berdasarkan besar tumor, sebagian besar pasien berada pada T2 yakni 35 pasien $(66,0 \%)$ dan nodul klinisnya didominasi oleh N0 sebanyak 37 pasien $(69,8 \%)$, 
Tabel 1. Karakteristik Subyek Penelitian

\begin{tabular}{|c|c|c|}
\hline \multirow{2}{*}{ Parameter } & \multicolumn{2}{|c|}{ Frekuensi } \\
\hline & Rata-Rata \pm SB & N (\%) \\
\hline Umur (tahun) & $51,8 \pm 10,3$ & \\
\hline \multicolumn{3}{|l|}{ Pekerjaan } \\
\hline Bidan & & $1(1,9)$ \\
\hline IRT & & $27(50,9)$ \\
\hline Perawat & & $1(1,9)$ \\
\hline Petani & & $2(3,8)$ \\
\hline PNS & & $10(18,9)$ \\
\hline Swasta & & $12(22,6)$ \\
\hline \multicolumn{3}{|l|}{ Suku } \\
\hline Bali & & $45(84,9)$ \\
\hline Luar Bali & & $8(15,1)$ \\
\hline \multicolumn{3}{|l|}{ Pendidikan } \\
\hline SD & & $9(17,0)$ \\
\hline SMP & & $6(11,3)$ \\
\hline SMA & & $17(32,1)$ \\
\hline PT & & $21(39,6)$ \\
\hline \multicolumn{3}{|l|}{ Besar Tumor } \\
\hline $\mathrm{T} 1$ & & $3(5,7)$ \\
\hline $\mathrm{T} 2$ & & $35(66,0)$ \\
\hline $\mathrm{T} 3$ & & $15(28,3)$ \\
\hline \multicolumn{3}{|l|}{ N KGB aksila } \\
\hline No & & $37(69,8)$ \\
\hline N1 & & $16(30,2)$ \\
\hline
\end{tabular}

KGB: kelenjar getah bening; SB: simpangan baku

Tabel 2. Hubungan antara Tumor Infiltrating Lymphocyte (TIL) dan Mitotic Activity Index (MAI) terhadap metastasis KGB aksila

\begin{tabular}{lccccc}
\hline \multirow{2}{*}{ Variabel } & \multicolumn{2}{c}{ Metastase KGB Aksila } & & & Nilai \\
\cline { 2 - 3 } \multicolumn{1}{l}{ TIL } & Positif (N,\%) & Negatif (N,\%) & RP & $\mathbf{9 5 \% ~ I K ~}$ & $\mathbf{P}$ \\
Low & $13(43,3)$ & $17(56,7)$ & 2,2 & $0,358-13,110$ & 0,627 \\
Intermediate & $9(50,0)$ & $9(50,0)$ & 2,5 & $0,408-15,320$ & 0,339 \\
High & $1(20,0)$ & $4(80,0)$ & ref & & \\
& & & & & \\
MAI & & & & & \\
$\geq 25 / 10 \mathrm{lp}$ & $6(54,5 \%)$ & $5(45,5 \%)$ & 1,6 & $0,721-3,412$ & 0,458 \\
$13-24 / 10 \mathrm{lp}$ & $9(47,4 \%)$ & $10(52,6 \%)$ & 1,4 & $0,654-2,835$ & 0,531 \\
$\leq 12 / 10 \mathrm{lp}$ & $8(34,8 \%)$ & $15(65,2 \%)$ & ref & & \\
\hline
\end{tabular}

diikuti dengan N1 16 pasien (30,2\%).

Pada Tabel 2 di bawah didapatkan sampel pasien dengan kadar TIL rendah yang mengalami kejadian metastasis KGB aksila sebanyak 13 pasien (43,3\%) dan yang tidak mengalami kejadian metastasis KGB aksila sebanyak 17 pasien (56,7\%).

Rasio prevalensi (RP) untuk kadar TIL rendah terhadap kejadian metastasis KGB aksila sebanyak
2,2 namun nilai interval kepercayaan sebesar $0,358$ - 13,110 ( $\mathrm{P}=0,627)$. Hasil penelitian ini menunjukkan bahwa tidak terdapat perbedaan yang signifikan secara statistik.

Hasil serupa juga ditemukan pada penilaian rasio prevalensi (RP) untuk TIL intermediate terhadap kejadian metastasis KGB aksila. Hasil penelitian menunjukkan bahwa tidak terdapat perbedaan yang signifikan secara statistik antara TIL intermediate dengan kejadian metastasis GB aksila $(\mathrm{P}>0,05)$.

Pasien dengan MAI $\geq 25 / 10$ lp yang mengalami kejadian metastasis KGB aksila sebanyak 6 pasien (54 5\%). Sedangkan sampel pasien dengan MAI 13-24/10 lp yang mengalami kejadian metastasis KGB aksila sebanyak 9 pasien (47, 4\%). Namun, hasil studi terhadap rasio prevalensi untuk pasien dengan MAI baik $\geq 25 / 10 \mathrm{lp}$ atau 13-24/10 lp dari hasil uji statistik menunjukkan tidak terdapat adanya hubungan bermakna dengan kejadian metastasis KGB aksila $(\mathrm{P}>0,05)$ (Tabel 2).

Untuk mengetahui hubungan antara TIL (Tumor Infiltrating Lymphocyte) dan MAI (Mitotic Activity Index) dengan kejadian metastasis KGB aksila pada pasien operable breast cancer dilakukan dengan uji regresi logistik dengan mengendalikan variabel umur, suku, pendidikan, besar tumor, klinis nodul aksila. Hasil analisis ditunjukkan pada Tabel 3.

Tabel 3 menunjukkan hasil analisis regresi logistik hubungan antara TIL (Tumor Infiltrating Lymphocyte) dengan kejadian metastase KGB aksila pada pasien operable breast cancer setelah dikontrol oleh variabel umur, suku, pendidikan, besar tumor, klinis nodul aksila, pada pasien dengan TIL low dengan adjusted OR sebesar 4,166. Hal ini menunjukkan pasien dengan TIL Low memiliki kemungkinan 4,166 kali lebih besar mengalami kejadian metastase KGB aksila pada pasien kanker payudara stadium dini dibandingkan pasien dengan TIL High, tetapi dengan nilai $\mathrm{P}$ sebesar 0,283 menunjukkan bahwa pasien dengan TIL Low tidak signifikan secara statistika sebagai faktor yang mempengaruhi kejadian metastase KGB aksila pada pasien operable breast cancer.

Sedangkan pada pasien dengan TIL Intermediate dengan adjusted OR sebesar 3,883. Hal ini menunjukkan pasien dengan TIL Intermediate memiliki kemungkinan 3,883 kali lebih besar mengalami kejadian metastase KGB aksila pada pasien operable breast cancer dibandingkan pasien dengan TIL High, tetapi dengan nilai P sebesar 0,309 menunjukkan bahwa pasien dengan TIL Intermediate tidak signifikan secara statistika sebagai faktor yang mempengaruhi kejadian metastase KGB aksila pada pasien operable breast cancer. 
Tabel 3. Hubungan antara TIL (Tumor Infiltrating Lymphocyte) dengan kejadian metastase KGB aksila pada pasien operable breast cancer

\begin{tabular}{lcccc}
\hline \multirow{2}{*}{ Variabel } & \multirow{2}{*}{ Adjusted OR } & \multicolumn{2}{c}{ 95\% IK } & \multirow{2}{*}{ Nilai P } \\
\cline { 3 - 4 } & & Lower & Upper & \\
\hline TIL Low & 4,166 & 0,308 & 56,331 & 0,283 \\
TIL Intermediate & 3,883 & 0,284 & 53,049 & 0,309 \\
TIL High & Ref & & & \\
Umur & 0,992 & 0,934 & 1,054 & 0,800 \\
Suku Bali & 1,207 & 0,187 & 7,783 & 0,843 \\
Suku luar Bali & Ref & & & \\
SMP & Ref & & & \\
SD & 0,307 & 0,58 & 1,616 & 0,164 \\
SMA & 0,589 & 0,094 & 3,688 & 0,572 \\
PT & 1,396 & 0,159 & 12,233 & 0,763 \\
T1 & Ref & & & \\
T2 & 0,771 & 0,052 & 11,498 & 0,851 \\
T3 & 2,084 & 0,133 & 32,758 & 0,601 \\
N0 & Ref & & & \\
N1 & 2,991 & 0,696 & 12,865 & 0,141 \\
\hline
\end{tabular}

Tabel 4. Hubungan antara MAI (Mitotic Activity Index) dengan kejadian metastase KGB aksila pada pasien operable breast cancer setelah kontrol variabel umur, suku, pendidikan, besar tumor.

\begin{tabular}{lllll}
\hline \multirow{2}{*}{ Variabel } & \multirow{2}{*}{ Adjusted OR } & \multicolumn{2}{c}{ 95\% IK } & \multirow{2}{*}{ Nilai P } \\
\cline { 3 - 4 }$\geq 25 / 10 \mathrm{lp}$ & 4,767 & 0,705 & 32,215 & 0,109 \\
$13-24 / 10 \mathrm{lp}$ & 2,334 & 0,572 & 9,533 & 0,238 \\
$\leq 12 / 10 \mathrm{lp}$ & Ref & & & \\
Umur & 1,002 & 0,943 & 1,064 & 0,955 \\
Suku Bali & 1,683 & 0,258 & 10,960 & 0,586 \\
Suku luar Bali & Ref & & & \\
SMP & Ref & & & \\
SD & 0,206 & 0,035 & 1,206 & 0,080 \\
SMA & 0,738 & 0,122 & 4,456 & 0,741 \\
PT & 1,125 & 0,133 & 9,512 & 0,914 \\
T1 & Ref & & & \\
T2 & 0,327 & 0,018 & 5,894 & 0,449 \\
T3 & 0,876 & 0,048 & 15,858 & 0,928 \\
N0 & Ref & & & \\
N1 & 4,506 & 0,892 & 22,759 & 0,068 \\
\hline
\end{tabular}

Hasil Tabel 4 berikutnya menunjukkan analisis regresi logistik hubungan antara MAI (Mitotic Activity Index) dengan kejadian metastase KGB aksila pada pasien operable breast cancer dikontrol oleh variabel umur, suku, pendidikan, besar tumor, pada pasien dengan $M A I \geq 25 / 10$ lp dengan adjusted OR sebesar 4,767. Hal ini menunjukkan pasien dengan MAI $\geq 25 / 10$ lp memiliki kemungkinan 4,767 kali lebih besar mengalami kejadian metastase KGB aksila pada pasien kanker payudara stadium dini dibandingkan pasien dengan MAI $\leq 12 / 10$ lp, tetapi dengan nilai $\mathrm{P}$ sebesar 0,109 menunjukkan bahwa pasien dengan $\mathrm{MAI} \geq 25 / 10$ lp tidak signifikan secara statistika sebagai faktor yang mempengaruhi kejadian metastase KGB aksila pada pasien operable breast cancer.

\section{PEMBAHASAN}

Kanker payudara merupakan jumlah kanker tertinggi pada perempuan di dunia. Berdasarkan estimasi International Agency for Research on Cancer (IARC) tahun 2014, kasus baru (insiden) kanker payudara sebesar 43,1 per 100.000 perempuan dengan angka kematian sebesar 12,9 per 100.000 perempuan. ${ }^{9}$

Estimasi insiden kanker payudara pada perempuan Indonesia tahun 2012 adalah 134 per 100.000 penduduk. Kanker payudara merupakan jenis kanker terbanyak, baik pada perempuan saja maupun pada seluruh populasi (laki-laki dan perempuan) di Indonesia, dengan estimasi insiden 40,3 per 100.000 perempuan atau 48.998 kasus baru per tahun. angka ini merupakan 30,5\% dari seluruh jenis kanker pada perempuan atau $16,4 \%$ dari seluruh jenis kanker pada laki-laki dan perempuan. ${ }^{10}$

Faktor prognostik yang paling penting pada pasien dengan kanker payudara adalah adanya keterlibatan metastase KGB aksila. Aliran KGB dari payudara penting dalam hubungannya dengan penyakit keganasan melalui kelenjar aksila dan kelenjar mamari interna. Kelenjar aksila menerima kira-kira $3 / 4$ dari total aliran KGB, dan ini menggambarkan besarnya frekwensi metastase tumor ke kelenjar ini. ${ }^{11-14}$

Penelitian yang dilakukan oleh Silverstein dkk melaporkan bahwa metastase kelenjar getah bening (KGB) dijumpai 3\% dari 96 pasien dengan tumor $\leq 0,5 \mathrm{~cm}$ dan $50 \%$ dari pasien ini menderita karsinoma insitu intra duktal dengan daerah-daerah yang didapati karsinoma mikro invasif. ${ }^{15}$ Data sebelumnya dari penulis menyatakan bahwa tumor yang terdeteksi dengan mamografi ("unpalpable tumor") memiliki insiden metastase KGB 7\% dan tumor yang teraba memiliki tingkat insidensi adanya metastase sebanyak $24 \% .{ }^{15}$ Hasil 
studi Silverstein juga menunjukkan bahwa ukuran tumor berhubungan dengan metastase KGB aksila tapi belum terbukti hubungannya dengan tipe histopatologi. ${ }^{15}$

Insiden metastase kelenjar getah bening aksila pada non palpable early breast cancer berkisar $10 \%$ - $27 \% .{ }^{16}$ Oleh karena itu penentuan adanya sentinel node pada kanker payudara sangat penting dilakukan sebelum operasi, sehingga diseksi kelenjar getah bening aksila yang tidak perlu dapat dihindari. ${ }^{17}$ Kira-kira $45 \%$ dari semua pasien palpable breast cancer terdapat metastase di aksila sesuai dengan metode pengecatan $\mathrm{H} \& \mathrm{E}$, ini berarti ada kemungkinan menyelamatkan setengah dari diseksi aksila yang tidak perlu. ${ }^{18}$ Oleh karena itu peranan diseksi lengkap kelenjar regional dipertanyakan dan menjadi kontroversi bila dilakukan pada tumor primer yang kecil. Akibat ketidakpuasan akan penatalaksanaan konvesional ini maka kedokteran onkologi berkembang, mencari solusi dengan teknik-teknik kedokteran yang maju. Di akhir abad 20 banyak penelitian yang berdampak pergeseran kearah pembedahan yang kurang invasif. Hal tersebut dipengaruhi oleh harapan masyarakat akan kebutuhan untuk pulih lebih cepat. ${ }^{19}$

Tumor padat umumnya terdiri dari berbagai sel kekebalan tubuh, termasuk limfosit $\mathrm{T}$ dan $\mathrm{B}$, sel NK, makrofag, dan neutrofil. Imunitas adaptif dan imunosupresi selalu menunjukkan tingkat ekspresi yang berbeda pada tumor, dan banyak gen kekebalan terkait dengan inflamasi. Interaksi antara sel imunitas menentukan induksi atau penghambatan perkembangan tumor, angiogenesis, dan metastasis. ${ }^{2}$

Limfosit yang rendah dikaitkan dengan outcome yang buruk.$^{20}$ Pentingnya limfosit telah diteliti pada beberapa penelitian. Limfosit dikaitkan dengan fungsi sitotoksiknya. Respon yang baik bila banyak limfosit yang infiltrasi ke sel tumor. ${ }^{21}$

Suatu studi tentang pengukuran serum perifer CD8 yang tinggi memiliki survival yang lebih baik dan pada penghitungan limfosit, didapatkan hasil outcome yang lebih baik pada limfosit yang tinggi. ${ }^{22}$

Peripheral serum limfosit signifikan lebih rendah pada pasien dengan lama survivor yang pendek. Limfosit mungkin menjadi suatu faktor host yang berperan dalam survival kanker payudara. Suatu penelitian menjelaskan korelasi positif antara kurabilitas pasien kanker dengan kadar limfosit dan korelasi negative dengan kadar neutrofil. ${ }^{23}$

Low dan intermediate TIL pada penelitian ini tidak dijumpai adanya hubungan yang bermakna, akan tetapi memiliki kecenderungan metastase KGB aksila pada pasien operable breast cancer. Kecenderungan metastasis ini dipicu oleh tingginya angka proliferasi pada sel kanker. Oleh karena itu proliferasi telah dikenali sebagai salah satu faktor prognostik kanker. ${ }^{24}$ Evaluasi dari derajat proliferasi sel dalam jaringan tumor digunakan untuk menilai progresifitas tumor. ${ }^{7}$ Salah satu metode yang paling sederhana dan masih digunakan hingga saat ini adalah menghitung jumlah mitosis dalam jumlah lapangan pandang tertentu (biasanya 10) pada lapangan pandang besar (400x). Penilaian indeks mitosis telah digunakan sebagai "gold standard" dalam menilai agresivitas tumor. ${ }^{8}$ Metode ini merupakan aplikasi yang berguna untuk evaluasi neoplasma mesenkimal (misalnya tumor otot polos), karsinoma payudara, neuroblastoma dan GIST. ${ }^{25}$ Oleh karena itulah hasil pada penelitian ini dijumpai adanya kecenderungan makin tinggi MAI, semakin tinggi resiko metastase KGB aksila pada pasien operable breast cancer, walaupun tidak dijumpai adanya hubungan bermakna.

\section{SIMPULAN}

Hasil penelitian ini menunjukkan bahwa tidak dijumpai adanya hubungan bermakna namun pada kadar low dan intermediate TIL diketahui memiliki kecenderungan metastasis KGB aksila pada pasien operable breast cancer lebih tinggi. Selain itu penelitian ini juga tidak menjumpai adanya hubungan bermakna antara MAI dan metastasis $\mathrm{KGB}$, namun terdapat kecenderungan makin tinggi MAI, semakin tinggi resiko metastasis KGB aksila pada pasien operable breast cancer.

\section{ETIKA PENELITIAN}

Penelitian ini telah mendapat persetujuan etik dari Komisi Etik, Fakultas Kedokteran Universitas Udayana, RSUP Sanglah, Denpasar, Bali

\section{KONFLIK KEPENTINGAN}

Tidak terdapat konflik kepentingan dalam penulisan laporan penelitian ini

\section{PENDANAAN}

Penulis bertanggung jawab dalam pendanaan penelitian ini tanpa melibatkan pihak sponsor, beasiswa, maupun berbagai sumber pendanaan lainnya.

\section{KONTRIBUSI PENULIS}

I Gede Aditya Krishna Santhi bertanggung jawab dalam pencarian sampel, analisis data penelitian, hingga pelaporan hasil akhir penelitian. I Nengah Wiadnyana Steven Christian dan I Gede Raka Widiana bertanggung jawab sebagai pembimbing dan menyempurnakan laporan akhir penelitian 


\section{DAFTAR PUSTAKA}

1. Suppan C, Bjelic-Radisic V, La Garde M, Groselj-Strele A, Eberhard K, Samonigg H, et al. Neutrophil/Lymphocyte ratio has no predictive or prognostic value in breast cancer patients undergoing preoperative systemic therapy. BMC Cancer. 2015; 15:1027

2. Zhu Y, Zhang M, Zhu B, Chen W, Jie Y, Chong Y, Meng $\mathrm{X}$. Predictive value of the tumor-infiltrating neutrophil-tolymphocyte ratio in patients with colorectal cancer. Int J Clin Exp Med 2016;9(7):14123-14131

3. Martínez-Lostao L, Anel A, Pardo J. How Do Cytotoxic Lymphocytes Kill Cancer Cells? Clin Cancer Res. 2015; 21(22):5047-56

4. Aaltomaa S, Lipponen P, Eskelinen M, Kosma VM, Marin $\mathrm{S}$, et al. Lymphocyte infiltrates as a prognostic variable in female breast cancer. Eur J Cancer. 1992; 28A(4-5): 859-864

5. Jobsen JJ, van der Palen J, Brinkhuis M, Nortier JW, Struikmans $\mathrm{H}$. The prognostic relevance of mitotic activity index in axillarylymph node-negative breast cancer. Breast Cancer Res Treat. 2015; 149(2):343-51.

6. Prabawa IPY, Bhargah A, Liwang F, Tandio DA, Tandio AL, Lestari AAW, Budiana ING, Manuaba IBAP. Pretreatment Neutrophil-to-Lymphocyte ratio (NLR) and Platelet-to-Lymphocyte Ratio (PLR) as a Predictive Value of Hematological Markers in Cervical Cancer. Asian Pac J Cancer Prev. 2019; 20(3):863-868.

7. Devianti L, Aswiyanti A, Edison. Peningkatan Ekspresi Ki-67 Tidak Berhubungan Dengan Parameter Prognostik Histopatologik Karsinoma Payudara Invasif di Sumatera Barat. Majalah Patologi Indonesia. 2012; 21(3):10-16.

8. Pirici A, Pirici E, Voinescu D, Cruce M, Bogdan F. Assesment of Cell Proliferation/Death Balance and Inflammation in Different Histological Variants of Basal Cell Carcinomas. Annals of RSCB. 2011; 16(1):254-261.

9. Winters S, Martin C, Murphy D, Shokar NK. Breast Cancer Epidemiology, Prevention, and Screening. Prog Mol Biol Transl Sci. 2017; 151:1-32.

10. Sobri FB., Azhar Y, Wibisana IGN G, Rachman A. Manajemen Terkini Kanker Payudara. Jakarta: Media Aeskulapius. 2017:1-9.

11. Harris JR, Morrow M. Treatment of Early-Stage Breast Cancer. In: Harris JR et al: Diseases of the Breast. Lippincot Raven, Philadelphia. 1996: 507-12

12. Love SM. Benign and Malignant Breast Diseases. In: Ritchie WP et al. General Surgery. JB Lippincott Co, Philadelphia. 1995:380-4.

13. Kambouris AA. Axillary Node Metastasis in Relation to Size and Incidence of Breast Cancer: Analysis of 147 Patients. The American Surgeons, Michigan. 1996:519-24.

14. Rosen PP. Invasive Mammary Carcinoma. In: Harris JR et al. Diseases of the Breast, Lippincott Raven Philadelphia. 1996:395-401
15. Silverstein MJ, Lagios MD, Recht A, Allred DC, Harms SE, Holland R, Holmes DR, et al. Image-detected breast cancer: state of the art diagnosis and treatment. J Am Coll Surg. 2005; 201(4):586-97.

16. Tanis PJ, van Sandick JW, Nieweg OE, Valdés Olmos RA, Rutgers EJ, Hoefnagel CA, et al. The hidden sentinel node in breast cancer. Eur J Nucl Med Mol Imaging. 2002; 29(3):305-11.

17. Schneider PM, Baldus SE, Metzger R, Kocher M, Bongartz $\mathrm{R}$, Bollschweiler E, et al. Histomorphologic tumor regression and lymph node metastases determine prognosis following neoadjuvant radiochemotherapy for esophageal cancer: implications for response classification. Ann Surg. 2005 Nov;242(5):684-92.

18. Newman LA. Epidemiology of locally advanced breast cancer. Semin Radiat Oncol. 2009; 19(4):195-203.

19. Sapino A, Cassoni P, Zanon E. Ultrasonographicallyguidednfinr-needle aspiration of axillary lymph nodes: role in breast cancer management. Br J Cancer. 2003; 88(5):702706

20. Noh H, Eomm M, Han A. Usefulness of Pretreatment Neutrophil to Lymphocyte Ratio in Predicting DiseaseSpecific Survival in Breast Cancer Patients. J Breast Cancer. 2013; 16(1):55-59

21. Templeton AJ, McNamara MG, Šeruga B, Vera-Badillo FE, Aneja P, Ocaña A, et al. Prognostic Role of Neutrophilto-Lymphocyte Ratio in Solid Tumors: A Systematic Review and Meta-Analysis. J Natl Cancer Inst. 2014; 106(6):dju124.

22. Rana AP, Kaur M, Zonunsanga B, Puri A, Kuka AS. Preoperative Peripheral Blood Count in BreastCarcinoma: Predictor of Prognosis or a Routine Test. Int J Breast Cancer. 2015; 2015:964392.

23. Akinbami A, Popoola A, Adediran A, Dosunmu A, Oshinaike O, Adebola P, Ajibola S. Full blood count pattern of pre-chemotherapy breast cancer patients in Lagos, Nigeria.Caspian J Intern Med. 2013:4(1):574-579

24. Haroon S, Hashmi AA, Khurshid A, Kanpurwala MA, Mujtuba S, Malik B, et al. Ki67 index in breast cancer: correlation with other prognostic markers and potential in pakistani patients. Asian Pac J Cancer Prev. 2013; 14(7):4353-8.

25. Kramer E, Herman O, Frand J, Leibou L, Schreiber L, Vaknine H. Ki67 as a biologic marker of basal cell carcinoma: a retrospective study. Isr Med Assoc J. 2014; 16(4):229-32.

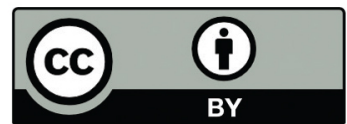

This work is licensed under a Creative Commons Attribution 